\title{
グループ発表からみた学生の授業参加と相互評価 Evaluation of Student Participation and Peer Assessment in Group Presentations
}

王崗

深圳大学

\section{要旨}

現在、中国の各大学では、様々な教育改革が行われている。この中で、学生 の授業参加や自主学習に関する実践活動や教育実験が多数ある。そしてそれに 伴う成果もたくさん紹介されている。ただし、全体的にみれば、中国の大学 教育の事情は、まだ改善しなければならないところがあると思われる。第一、 いわゆる教師主導という授業形態がまだ根本的に是正されていないように 思われる。日本語教育の分野においても、まったく同じようなことがみられる。 関連する実践例が少ないうえに、従来の報告や研究に対する検証や分析もめった になされていないようである。そこで、そういう現状の打開及び日本語教育の 更なる活性化と多様化を図るために、本研究では独自の教育的模索を繰り広げて みた。具体的には、教室では学生同士の相互評価を導入し、受講者たちにより 積極的に授業参加させる取り組みを行った結果、この相互評価の導入の取り 組みを通して、学生たちに従来みられた散漫だった授業態度を改善できたのと 同時に、比較的真面目に発表者への評価を下すことができた、ということが わかってきた。ただし、今回、参加した教員と学生との間には、発表者に対する 評価が㛜格か否か、日本語能力の高低への認識差などで生まれた、評価面での 違いもみられた。

キーワード：グループ発表、授業参加、相互評価、授業態度 


\section{王 崗 深圳大学}

\section{1.はじめに}

現在、中国の各大学では、中国教育部からの教育指導方針に基づき、様々な 教育改革が実施されており、多数の研究や実践事例が報告されている。しかし、 筆者の知るかぎり、確かに一部の改革成果がみられるようになってきているが、 肝心な授業の進め方にはいまだに根本的な変化が見られないように思われる。 その要因の一つは、中国の学生が、小学校から大学まで、基本的に教師主導の 授業を受けてきており、その受動的な学習の姿勢に完全に染まっているため、 短期間の間にその受講姿勢が根本的に改善されることはかなり難しいことと 考えられる。それに加えて、例えば時代にそぐわない旧来の科目や課程の設計、 さらに㛜格な授業進度の管理、教材内容の限定、そして教育者自身の専攻背景 の不具合など、教育改革を円滑にかつ効率よく実施する上でのハードルが多く あると考えられる。中国国内における各大学の日本語学科においてもまったく 同じような状況がある。そのため、教育改革をより効率的に推し進めるには、 このような従来からある様々なハードルを乗り越えていかなければならない。 その一つとして、まず学生たちの既有の授業姿勢を何とか打ち破ることが重要 である。そこで、筆者は、その試みとして、勤務校で学生たちによるグループ 発表と相互評価 ${ }^{1}$ 、しかも各評価の平均点がそれぞれの発表者の総合成績の 一部になるというような教授法を導入し、それをもって学生たちにより能動的 に授業参加させられるかどうかという実践活動を展開し、その効果を検証した。

\section{2.これまでの研究概要}

これまでの研究を概観すると、学生たちの授業参加及び相互評価に関する 研究や論考が豊富に存在するのがわかる。それは従来のトップダウン式の教育 指導法では学生たちの学習意欲を高めることが難しく、いかに学生たちに積極的 に授業参加させるのか、という研究者たちの高い関心と深く結びっく。例えば、 梁紅衛（2014） は、英語教育にける学生同士の協同活動に関する研究を行って いる。それによると、学生同士の協同学習を通して、学生間の合同学習能力と 言語運用能力が磨かれるという。また、王芳（2017）では、「企業経営」と いう授業を通じて学生による相互評価への実証研究を行ったが、評価の導入で 学生たちに経営例の各方面の討論に参加させることができ、学生たちの専門 知識の獲得を促進したり、言語表現能力、判断力の向上ができたと指摘している。 1 相互評価とは学習の主体である生徒・学生自身が評価の主体となる方法である（石橋 潔
2010 参照）。 
一方、黄乃佳（2016）によれば、中国の「国語」科において、学生による相互 評価の実施で、その学習における能動性を促せるだけでなく、学生たちの言語 使用能力、創意工夫における意識の向上が鍛えられ、効果的な国語教育を推進 できるものと考えられる。

日本の研究においては学生たちの授業参加や相互評価の報告が数多い。例えば、 堀越泉・田村恭久（2017）がある。この報告では、学生による相互評価において 評価タイミングを含めて信頼性・妥当性を分析したが、評点の一致度をもとに した従来の手法ではその信頼性・妥当性が中程度と判定され、評価タイミング は必ずしも一致していないという結果をまとめている。また、山本恭子・河野 浩之（2010）では、学生同士の評価が彼らのプレゼンテーション能力の上達、 ならびにプレゼンテーション評価能力の向上に寄与したと述べている。

日本語学習者対象の研究としては、趙冬茜（2012）があげられる。趙冬茜 (2012) では、「日本事情」という多人数の授業で協同学習の実践活動を導入 し、その効果についてグループ調査法の形で学生たちに自己評価と相互評価を

してもらったところ、学生の大半は協同学習の導入に肯定的であること、一定 の自主的な学習の意欲と能力を持っていること、教師による指導のもとで知識 探求欲を高めたいことを明らかにした。

上述の研究を見渡せば、学生たちの授業参加や相互評価の導入は、該当の 教育目標を達成できるの夕ならず、学生たちの向学心や学習動機を向上させる ことを示唆する。ただし、学生たちが真面目に評価をしているのか、学生と教師 の評価にずれがあるのか、または一致性があるのかなどについては、現時点の 先行研究では明確に言及されているものがまだ少ないように思われる。以下、 本研究の試みを通じてその検証を行う。

\section{3. 学生の授業参加と相互評価への試み}

\section{1 グループ発表と学生相互評価導入の動因}

筆者は、勤務校で「総合日本語」という授業を担当している間に、授業中に よく質疑応答があったものの、教師からの一方通行による、個別な質問にしか 答えられない学生たちの授業態度に触れるたびに、それが教育者として追求し ている理想的授業の進め方でもなければ、面白い授業でもないと痛感し、打開 策を模索してきた。そこで、タスクの一環として、学生たちに自分の意志で $6 つ$ のグループに分けさせ、テキストの内容や練習問題から発展的な話題を選ばせ、 事前準備をさせたうえ、日本語で順次発表という実践活動を試みることにした。 


\section{グループ発表からみた学生の授業参加と相互評価}

また、今回の研究動機には理由がもう一つある。現在、中国の地方大学の 日本語教育において最も不足する深刻な課題として、学習者たちの会話力の低さ という点がよくあげられる。日本語を使える場がほとんど教室に限られるという 学習環境にいるため、学習者たちに会話を上達させることが極めて困難である。 それにもまして、教師が授業を主導する、いわゆる一方通行的な教授法を依然 として採用している大学がまだ多い。その教室においても日本語をうまく使え ない学生が非常に多い。従って、クループ発表の導入によって、会話力を含め、 学生たちの日本語の総合能力を向上させるという大きな教育目標と研究動機が 背景になる。

以前、これと類似した実践活動をやはり勤務校で筆者自身が「日本事情」 などの授業で取り組んだことがある、しかし、そのときは、発表者が一生懸命に プレゼンテーションをしている最中も、聞くべき者の、携帯をチェックしたり、 漠然とした表情を浮かべたり、つまらなげに教科書をめくったりするという、 思わず首をかしげたくなるような授業態度に悩んできた苦い過去がある。そこ で、今回、「総合日本語」においては、5つの評価項目をもとに、学生たちに 発表者の発表に対して評価点をつけさせ、それと同時に担当教員も評価点を 同じようにつけ、学生の出した平均点に教師の評価点を加点し、それを当該 発表者の成績 ${ }^{2}$ の一部とするといった新しい試みを実施、導入した。つまり、 彼ら自身の評価が成績になるということで、発表者側はより真剣な態度が期待 され、しかも評価する側にも責任が生じ、より客観的な評価の結果が得られ やすくなると考えた。さらには、担当教員の評価と比較することで、両者に見 いだされる共通性、違いが何かも同時にみたかった。

\section{2 相互評価の実施期間及び対象者}

相互評価の実施にあたり、対象を日本語学科の 3 年次生に限定しておいた。 それは、当該年次の学習者の日本語力がタスク遂行を大体支えることができる からである。詳しくは以下のようにまとめる。

表 1 相互評価の実施期間及び対象者の内訳

\begin{tabular}{|c|c|c|c|}
\hline 対象 & 年齢 & 期間 & 性別(人数) \\
\hline 3 年次日本語専攻生 & 20 才〜23才 & $2017.09-2017.12$ & 男（6）女（19) \\
\hline
\end{tabular}

2 こでいう成績とは平常点とよばれる、実際の総合成績の一部である。 


\section{3 相互評価の実施方法と評価項目}

相互評価実施のクラスには全部で 25 名の受講者がいるが、学生個人の意思 で 6 つのグループに分けられた。グループ発表の日付や話題などについて、 それぞれ発表開始の数週間前に予告をしておいた。次にその詳細をまとめる。

表 2 グループ発表の実施方法と発表テーマ

\begin{tabular}{|c|c|c|c|}
\hline 組別 & 時間 & テーマ & 人数 \\
\hline 第一組 & 2017.09 .18 & アーカイブズの話 & 5 人 \\
\hline 第二組 & 2017.10 .23 & ボランティアの体験 & 4 人 \\
\hline 第三組 & 2017.11 .20 & アンケート発表 & 4 人 \\
\hline 第四組 & 2017.12 .12 & 統計の話 & 4 人 \\
\hline 第五組 & 2017.12 .19 & ネーミングの話 & 5 人 \\
\hline 第六組 & 2017.12 .25 & 漢字と漢文 & 3 人 \\
\hline
\end{tabular}

テーマによるが、基本的に 1 グループにつき、20 分〜30 分の発表時間を 設けておいた。なお、上記の表にある各テーマはすべて教材『基礎日本語総合 教程 4』（趙華敏 2011）の各単元で学習する内容にしたが、場合によっては、 それと関連する課外タスクを中心としたものもあった。

また、評価に際して、下記のように、発表を聞く学生たちに評価項目と配当点 が載っている無記名の評価シートを配布し、評価点を記入したうえ提出させる。

\section{表 3 評価シートの例}

$$
\begin{aligned}
& \text { 第一組 } \\
& \text { テーマ:アーカイブズの話 }
\end{aligned}
$$

(日付：2017.09.18)

5 非常に良い 4 良い 3 普通 2 あまり良くない 1 良くない

\begin{tabular}{|l|l|l|l|l|l|}
\hline \multicolumn{1}{|c|}{ 評価項目 } & 学生 1 & 学生 2 & 学生 3 & 学生 4 & 学生 5 \\
\hline 問題指摘は明晰なのか & & & & & \\
\hline 事例の提供と改善策が妥当か & & & & & \\
\hline 今後の課題はあったか & & & & & \\
\hline 表現は豊富か & & & & & \\
\hline 全体の印象 & & & & & \\
\hline
\end{tabular}




\section{グループ発表からみた学生の授業参加と相互評価}

\section{4 相互評価の結果分析}

\section{4.1 評価の結果}

各グループの発表者に対して、聴講の学生たちと教員がそれぞれどのように 評価をつけたのだろうか。以下、その集計の結果をみていく。
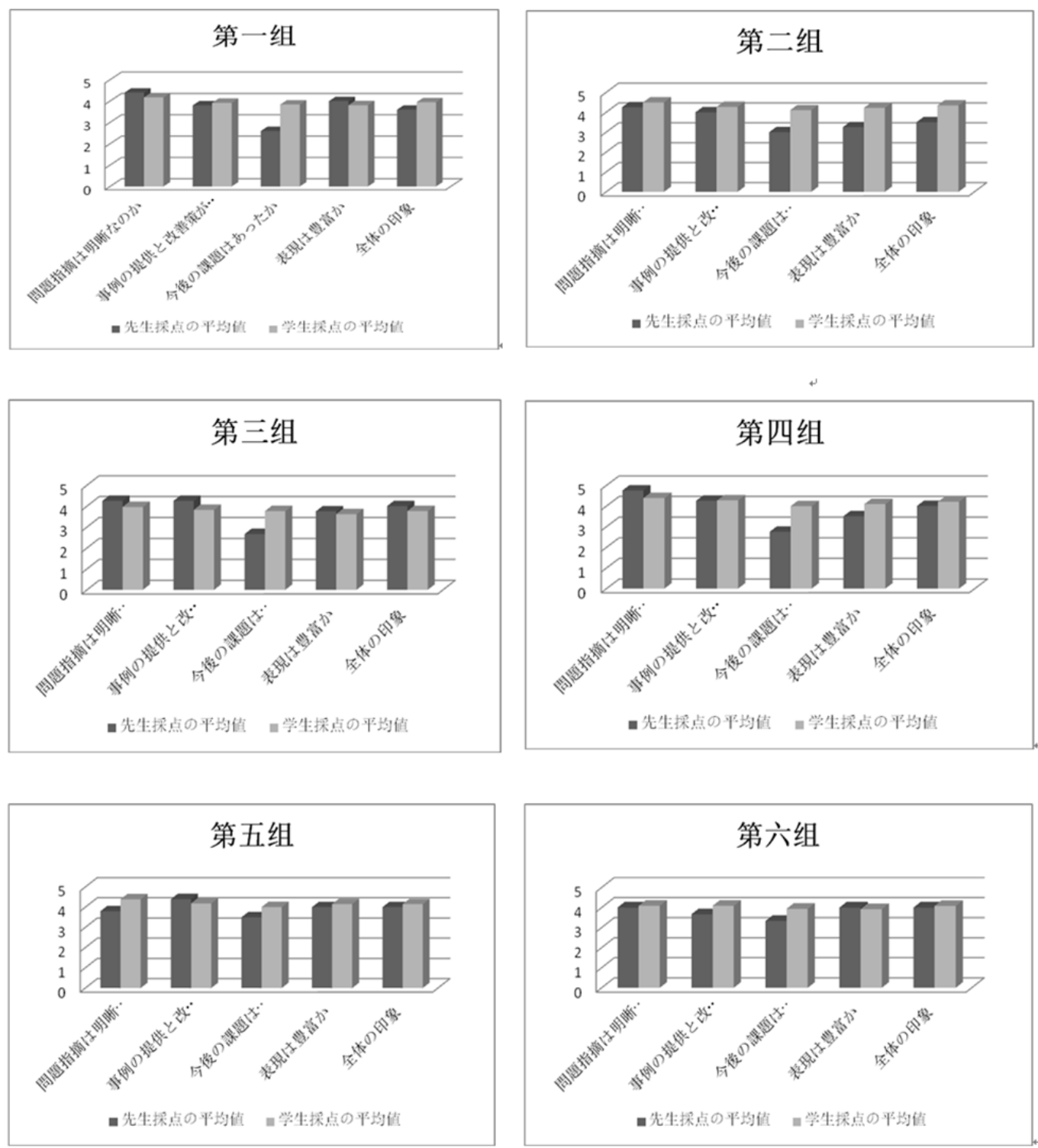


\subsection{2 結果の分析}

上記のグラフを見比べたところ、6グループの発表者への評価において興味 深いことに気が付いた。以下のように整理する。

\section{ア．評価の一致性}

グラフにも一応示されているが、6つのグループに対して、学生と教員の評価 においてはっきりした差異はあまり目立たず、かえって一致している部分が 比較的多いようにみえる。これについて、さらにSPSS の統計ソフトでピアソン 相関係数を分析したところ、5\%水準で比較的高い相関が認められた $(\mathrm{r}=.829, \mathrm{p}<.05)$ 。つまり、教員の評価を基準值にしてみれば、全体的には学生 の評価值がかなり教員の評価值に近いということである。これは、評価者たち が各グループの発表者に対して積極的に評価に臨んだことを物語っている。 言い換えれば、学生評価者の多くは、個人の好みや人間関係などで評価を下す のではなく、実際に見聞きした感想をもとに客観的な評価を下すことに努めた と考えられる。それは、評価のばらつきがあまり顕著ではなかったことからも そういえるだろう。

\section{イ. 極端な評価が比較的少ない}

相互評価を導入した目的には、以前のように散漫な授業態度ではなく、学生 たちに少しでも真面目に授業参加させようとした狙いがある。そのため、以前 の反省を生かして、上述したように、相互評価の実施にあたっては、評価シー トの配布に加え、その評価点を総合成績の一部にするという方法を取り入れた。 結果的には、実際の発表を聞いた感想としては、日本語の良し悪しは別として、 とにかく発表者全員は、しっかりと事前準備をし、最大限の努力をしてグルー プ発表に臨む様子が見て取れた。発表を聞く学生たちもむろん、学友のその真 摰かつ真面目な態度と努力を受け止めたわけで、評価をするときに「3 普通」 以上の評価をつけた者が多いが、「2あまり良くない」、「1良くない」と極 端な低評価を記入したサンプルは少なかった ${ }^{3}$ 。一方、教員でも評価者でも最 高ランクの「5非常に良い」と評価したケースがあったことから、自他ととも に優れた発表だと認めたことや、学生にも独自の、大人らしい判断力があった ことの現れだといえよう。

3 この場合、学友、寮友など人情関係を考慮した要素もあるとは否めないことだが、逆に ライバル意識や競争関係で学友同士でも甘くみられない事情もある。よって、全体的に 評価のばらつきが目立たないのは、発表者の努力と、それに対する評価者の納得があった ためだということがいえるのではないかと思われる。 


\section{グループ発表からみた学生の授業参加と相互評価}

\section{ウ. 教員と学生間の評価差}

教員と学生の間には、評価上の相違もみられた。それは、主に「今後の課題は」 という項目と、第二組の各項目に集中していた。以下、簡単な分析を加える。

まず、「今後の課題は」の項目をみてみよう。面白いことに、全グループの 発表者に対して、この項目における学生の評価は、教員のより高いということ

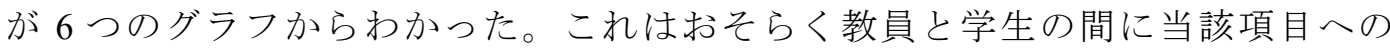
認識、捉え方の差によったのではないかと思われる。例えば、「ボランティア の体験」という話題について、教員としては、発表者に、ボランティア活動に 参加するときに起こりがちな問題や悩みなどに今後の課題としてどう対応する のかなど、もう少し包括的に話してもらいたかったのだが、それがないため 点数をやや下げたのである。これに対して、学生たちは、発表者の話にはそれ にちらっと触れただけでそのまま今後の課題が話されたと認識し、それなりの 点数をつけたようにみえる。評価の差はこのように生まれたのであろう。

次に、第二組の各項目をみよう。第二組の集計結果について、該当の発表者と 当時の発表の様子を評価シートとメモ用紙を参考にしながら調べてみたところ、 発表者 4 人中の 2 人が日本語能力がまだそれほじ上達していないため、当該 グループ全体の完成度と表現力を少し引き下げたことで、点数をやや低くした。 ただし、日本語能力の高低に関しては、教員と学生たちの間に確かに認識の ギャップがある。一般的に、教員としてはやや目が㛜しいが、学生としては甘め にみる傾向がある。これが結局、第二組における評価上の差をもたらしたこと に繋がっているのであろう。

\section{エ. 聴講態度の変化}

先の「3.1」節にも触れたことであるが、以前にグループ発表が授業に導入 されたときに、多くの学生は、発表者への態度がかなり散漫で、携帯チェック をしたり、漠然とした表情だったりしていて、発表が形である授業参加への 意欲が非常に低かった。しかし、相互評価プラス評価点の提出という方法が グループ発表に組み込まれた後、教室現場では学生たちの態度が一変したこと が観察できた。例えば、真面目に発表者の話を聞いたり用意されたスライドを きちんと鑑賞したりした学生が増えた。これにとどまらず、真剣にメモ付けや 採点をしたり、まともに発表者の質問に答えたりした学生の姿なども多く確認 できた。このような積極的な態度と相まって、前出のグラフに示されている 
ような、学生と教員の間における評価の多くの一致がみられたのだと思う。 これらはいずれもが学生たちの意欲的な授業参加の一面を映し出しているの ではないかと考える。

\section{4. おわりに}

中国の大学教育は、今日でもまだ多くの難問を抱えている。それを一つ一つ 改善し、乗り越えていくためには、依然として教育者たちの弛まめ努力が必要 である。本研究は、そういった教育者としての教育的使命から、日本語教育の 活性化と多様化を図ろうとして、独自の教育的模索を繰り広げた。具体的には、 教室では学生同士の相互評価を導入し、学生たちにもつと積極的に授業参加 させようとした。そして、一連の実践活動を通じて、相互評価の取り入れを もって、学生たちに従来みられた散漫な授業態度を改善できたのと同時に、 比較的真面目に発表者への評価を下していることなどがわかってきた。これは、 学生の評価值が教師の評価值にかなり接近している点からもみて取れる。当然、 教員と学生との間には、発表者をみる目の厳しさや日本語能力の高い低いなど の認識差などの要因から評価面での違いもみられた。

相互評価の導入は、学生たちの学習能力と日本語の伝達能力の向上も期待 できることがわかった。これは、当クラスの学生が当該学年後期の発表、4 年 次時点での発表から明らかになったことであるが、詳しくは別稿で論じる。

最後に不足な点として、調査項目と参加者が少ないため、統計上の有意差及び 相関関係などへの言及を全体的に控えざるを得なくなったことが、本研究の データ分析の厳密性に一定の弱化をもたらしたことがあげられる。また、実践 活動後のインタビューやアンケート調査を十分に行えなかったり、実践の独創 性に欠けたりすることは、今後の課題である。以後、これらの不足の点を修正 しながら、引き続き教育実践及びそれに関する研究を続けていきたい。

\section{付記}

本稿は、“2016 年度深圳大学教学研究改革項目”（課題番号：JG2016027）の研究助成 を受けたものである。なお、原稿のデータ集計は、深圳大学日本語学科大学院生の王逸良 さんにしてもらったのだが、統計の責任がすべて筆者にある。また、原稿の作成にあたり、 深圳大学日本語学科の日本人教員先生の松永源二郎氏から多大なご協力をいただき、 記して感謝の意を表する。最後に、査読の方々より貴重なコメントをいただいたことも 深謝申し上げたい。 


\section{グループ発表からみた学生の授業参加と相互評価}

\section{参考文献}

石橋潔（2010）「レポート相互評価法一大学における授業実践の試み」『久留米大学文学部 紀要 情報社会学科編』第 5 号、pp.17-33.

王芳（2017）「学生互評効果的実証研究」『高等教育研究学報』第 40 卷第 4 期、pp.86-90. 黄乃佳（2016）「語文課堂視闇下学生互評的価值取向与策略探析」『欽州学院学報』

第 31 卷第 12 期、pp.54-62.

趙華敏（2011）『基礎日本語総合教程 4』高等教育出版社

趙冬茜（2012）「合作学習在日本概況課大班課堂上的応用研究」『黑龙江教育学院学报』

第 31 卷第 10 期、pp. 50-53.

堀越泉・田村恭久（2017）「学生の相互評価における評価タイミング取得の必要性」学習 分析学会第 1 回研究会(2017-5) (jasla.jp/new/wp-content/uploads/2017/05/JASLA_Horikoshi.pdf 2018.11.15 アクセス)

山本恭子・河野浩之（2010）「学生の相互評価によるプレゼンテーション能力向上」『論文 誌 ICT 活用教育方法研究』第 13 卷第 1 号、pp.46-50.

梁紅衛（2014）「英語教学中応用生生互動模式的行動研究」『福建江夏学院学報』第 4 卷 第 1 期、pp.101-106. 